\title{
Euidence of the Effect of Winning or Losing in Levels of finger and Anxiety in Judo Fighters
}

\author{
Euidencia del efecto de ganar o perder en los niveles de rabia y ansiedad en \\ luchadores de judo \\ Euidências do efeito de ganhar ou perder em níveis de raiua e ansiedade em lutadores \\ de judô
}

\author{
Héctor Andrés Páez-Ardila* \\ Ítalo Sergio Lopes Campos \\ Amauri Gouveia Jr. \\ Universidad Federal de Pará
}

Doi: https://doi.org/10.12804/revistas.urosario.edu.co/apl/a.6950

\begin{abstract}
fibstract
Aggression is a behavior that involves a simultaneous activation of physiological, biochemical, neurological, and behavioral components and emotions, such as anxiety and anger. In humans, sports can be considered as a form of display because they allow aggression to be expressed with a low probability of permanent damage to subjects. The competitions have been used as models to evaluate the activation produced by its different stages, such as the outcome of the combat. Judo has been used as a model of competitive aggression to evaluate the different body responses in agonistic behaviors in humans since it offers a context to those studied in animal fights. The aim of this study was to evaluate the effect of winning/losing in the levels of anger and anxiety in regional male judo fighters, linked to the Pará Federation of Judo, Brazil. The STAXI and STAI psychometric scales and their results were used in
\end{abstract}

a correlation analysis to know the interaction between the components of the scales with the total number of strikes, using a pre/post fight evaluation and the filming of the fights. Significant statistical differences $(p<0.05)$ were found between winners and losers. Losers had higher levels of anger, while anxiety was higher for the winners, being that judo is a mean of competition in which such behaviors can be expressed in a socially accepted way.

Keywords: Defensive aggression; offensive aggression; sport; anxiety; anger.

\section{Resumen}

La agresión es un comportamiento que implica una activación simultánea de componentes fisiológicos, bioquímicos, neurológicos, conductuales y emocionales como la ansiedad y la rabia. En los humanos, los deportes pueden considerarse una forma de exhibición

* Address correspondence to Héctor Andrés Páez-Ardila. Universidad Federal de Pará, — Bélem/Pará/Brasil— E-mail: hpaez71@ gmail.com

To cite this article: Páez-Ardila, H. A., Lopes Campos, I. S., Gouveia Jr., A. (2020). Evidence of the Effect of Winning or Losing in Levels of Anger and Anxiety in Judo Fighters. Avances en Psicología Latinoamericana, 38(2), 1-18. https://doi. org/10.12804/revistas.urosario.edu.co/apl/a.6950 


\section{Héctor Andrés Páez-Ardila, Ítalo Sergio Lopes Campos, fmauri Gouveia Jr.}

porque permiten que la agresión se exprese con una baja probabilidad de daño permanente a los sujetos. Las competiciones se han utilizado como modelos para evaluar la activación producida por las diferentes etapas de la competencia, como el resultado del combate. El judo ha sido utilizado como un modelo de agresión competitiva para evaluar las diferentes respuestas del cuerpo en comportamientos agonísticos en humanos, ya que ofrece un contexto similar a los estudiados en peleas de animales. El objetivo de este estudio fue evaluar el efecto de ganar/perder en los niveles de rabia y ansiedad en luchadores de judo vinculados a la Federación de Judo de Pará, Brasil. Se utilizaron las escalas psicométricas STAXI y STAI, y sus resultados fueron usados en un análisis correlacional para conocer la interacción entre los componentes de las escalas con el número total de golpes, utilizando una evaluación pre/post lucha y la filmación de las peleas. Se encontraron diferencias entre ganadores y perdedores estadísticamente significativas $(\mathrm{p}<0.05)$; los perdedores presentaron mayores niveles de rabia, mientras que la ansiedad fue mayor en los ganadores, debido a que el judo es un medio de competición en el que pueden expresarse de manera socialmente aceptada dichos comportamientos.

Palabras clave: agresión defensiva; agresión ofensiva; deportes; ansiedad; rabia.

\section{Resumo}

A agressão é um comportamento que implica uma ativação simultânea de componentes fisiológicos, bioquímicos, neurológicos, comportamentais e emocionais tais como a ansiedade e a raiva. Nos humanos, os esportes se podem considerar como uma forma de exibição porque permite que a agressão se expresse com uma baixa probabilidade de dano permanente aos sujeitos. As competições se têm empregado como modelos para avaliar a ativação produzida pelas diferentes etapas da concorrência como o resultado do combate. O Judô tem sido usado como um modelo de agressão competitiva para avaliar as diferentes respostas do corpo em comportamentos agonísticos em humanos, pois oferece um contexto similar aos estudados em brigas de animais.
O objetivo deste estudo foi avaliar o efeito de ganhar/ perder nos níveis de raiva e ansiedade em lutadores de judô já vinculados à Federação de Judô de Pará, Brasil. Se utilizaram as escalas psicométricas STAXI e STAI e seus resultados foram usados em uma análise de correlação para conhecer a interação entre os componentes das escalas com o número total de golpes, utilizando uma avaliação pre/pós briga e a filmagem das lutas. Encontraram-se diferenças entre ganhadores e perdedores estatisticamente significativa $(\mathrm{p}<0.05)$; perdedores apresentaram maiores níveis de raiva, enquanto a ansiedade foi maior para os ganhadores. Sendo que, o judô é um meio competição, onde podem expressar-se de forma socialmente aceitada, ditos comportamentos. Palavras-chave: agressão defensiva; agressão ofensiva; esportes; ansiedade; raiva.

Martial arts originated from different fighting techniques that were applied in excessive and non-ritualized aggressive confrontations. Judo has been used with a competitive aggression model to study the neuroendocrine response in humans' fighting behaviors since it provides a context similar to those found in the daily encounters studied in animals (Geniole, Bird, Ruddick, \& Carré, 2017; Parmigiani et al., 2009; Salvador, Suay, Gonzalez-Bono, \& Serrano, 2003). In natural situations, aggressive behavior is used to maintain or obtain resources, such as social status, territory, food, and access to partners for reproduction (Martínez-Díez, 2008). In this way, aggression is a behavior that attends to a determined function, triggered by a stimulus that generates a behavioral response and a physiological and biochemical activation that allows individuals to react to situations that could endanger their life or resources.

The biochemical and neuroanatomic basis of interspecific and intraspecific aggression, as well as its manifestations have been explored in different researches regarding their pharmacology and chemistry (Ariás-Carrion, Stamelou, Murillo-Rodriguéz, Menéndez-González, \& Pöppel, 2010; 
Siever, 2008; Takahashi, Shimamoto, Boyson, Debold, \& Miczek, 2010), behavioral expression (Alcazar-Corcoles, Verdejo-García, Bouso-Saiz, \& Bezos-Saldaña, 2010; Montás, 2011; Rosell \& Siever, 2015; Siever, 2008; Verona, Patrick, Curtis, Bradley, \& Lang, 2004), and physiology (Alcazar-Corcoles et al, 2010; Siever, 2008; Von Borries et al., 2012) — see table 1.

A trait used to study the agonistic behavior in animals is the aggressive display, defined as the patterns of behavior that allow transmitting different types of information (Paton \& Caryl, 1986). In general, fights always start with sensory expressions designed to discourage the candidate from starting combat, reducing the possibility of harm and death (Blank, Ruckstuhl, \& Yang, 2015). In humans, sport is considered a ritualized agonistic struggle characterized by games, where the conflicting members win the reward and prevent the other group from winning it, the aggression used tends to be symbolic and destined to gain victory, even before the opponents have been defined (Se- bastián, 2013). Using aggressive display to gain a tactical advantage in the confrontation that allows increasing the probability of victory will be a way to choose the best components to be transmitted to the next generation (Huber, Bannasch, \& Brennan, 2011). Considering that humans also fight for different rewards in sports, we may conclude that socially constituted prices, such as money or a better job position, are objectives of disputes that are also beyond those found in animals (Dos Santos, Junior, Torralba, \& Lopez, 2017; Schiphof-Godart, Roelands, \& Hettinga, 2018).

It seems that in many species, there is an effect related to the result of an encounter between conspecifics, called winning or losing; winning a fight increases the likelihood of future wins, and losing will increase the risk of losing in the future (Geniole et al., 2017; Ouergui et al., 2016). The winning-losing effect is considered adaptive, since participation in fights will decrease or increase, regarding the last social experience (Lehner, Rutte, \& Taborsky, 2011; Trannoy \& Kravitz, 2017; Zhou et al., 2017).

Table 1.

Types of Aggressions, according to object, trigger stimulus pattern, observed behavior, and affection, as well as indication of possible associated brain areas and neurochemistry

\begin{tabular}{|c|c|c|c|c|c|c|}
\hline Aggression & Object & $\begin{array}{l}\text { Triggering } \\
\text { Stimuli }\end{array}$ & Behavior & $\begin{array}{l}\text { Involved } \\
\text { affection }\end{array}$ & $\begin{array}{l}\text { Areas of brain } \\
\text { involved }\end{array}$ & Neurochemistry \\
\hline \multirow{3}{*}{ Defensive } & $\begin{array}{l}\text { Defense of } \\
\text { predation }\end{array}$ & $\begin{array}{c}\text { Presence of } \\
\text { predator }\end{array}$ & $\begin{array}{l}\text { Avoidance / flight / } \\
\text { avoidance }\end{array}$ & Fear / anxiety & \multirow{3}{*}{$\begin{array}{c}\text { Insula } \\
\text { Amygdala } \\
\text { Thalamus } \\
\text { Hypothalamus } \\
\text { Rafe } \\
\text { ATV } \\
\text { Accumbens }\end{array}$} & \multirow{3}{*}{$\begin{array}{c}-5-\mathrm{HT} \\
-\mathrm{NA} \\
+ \text { Cortisol } \\
-\mathrm{TES} \\
+\mathrm{DA} \\
\text {-GABA }\end{array}$} \\
\hline & $\begin{array}{l}\text { Co-specific } \\
\text { defense }\end{array}$ & $\begin{array}{l}\text { Competition for } \\
\text { feature }\end{array}$ & Fight / display & Fear / anxiety & & \\
\hline & $\begin{array}{l}\text { Defense of } \\
\text { the offspring }\end{array}$ & $\begin{array}{l}\text { Risk of loss of } \\
\text { offspring }\end{array}$ & $\begin{array}{c}\text { Fight / display / } \\
\text { avoidance / } \\
\text { Escape / avoidance }\end{array}$ & Fear / anxiety & & \\
\hline \multirow[t]{2}{*}{ Offensive } & Predation & $\begin{array}{l}\text { Physiological } \\
\text { need (hunger) }\end{array}$ & Hunting & $\begin{array}{c}\text { Hunger / } \\
\text { deprivation / } \\
\text { will / desire }\end{array}$ & \multirow{2}{*}{$\begin{array}{l}\text { Thalamus } \\
\text { Insula } \\
\text { Amygdala } \\
\text { Pre-optical area } \\
\text { Hypothalamus }\end{array}$} & \multirow{2}{*}{$\begin{array}{l}+ \text { Cortisol } \\
+ \text { TES } \\
+ \text { GABA } \\
-5-\mathrm{HT}\end{array}$} \\
\hline & $\begin{array}{l}\text { Intraespecific } \\
\text { (dispute) }\end{array}$ & $\begin{array}{l}\text { Competition for } \\
\text { feature }\end{array}$ & Fight / display & Anger & & \\
\hline
\end{tabular}

Acronym: ATV: Ventral Tegumentary Area; 5-HT: serotonin; NA: Noradrenaline; TES: Testosterone; DA: Dopamine; GABA: Gamma-a butyl butyric acid; +: Increase; -; Decrease 


\section{Héctor Andrés Páez-Ardila, Ítalo Sergio Lopes Campos, fmauri Gouveia Jr.}

\section{Anxiety and Anger in Combat Sports}

The emotional responses of athletes are fundamental aspects in their performance and training, both sports and psychological. The competitive experience and the type of sport will influence the interpretation that the athletes make of the behaviors, it will be affected by the previous results, level of anxiety and anger, among other components (García, Zafra, \& Toro, 2008; Gómez, Sánchez, Sánchez, \& Amarillo, 2016).

Sports practices and competitions are considered stressful situations for each of the people participating in them, due to the stress produced. Different negative states may arise in the competitors, anxiety is one of those that has been studied in the context of competition (Peña \& Oreja, 2019; Pulido, Fuentes, \& De la Vega, 2019; Strahler, Berndt, Kirschbaum, \& Rohleder, 2010) since it appears before and during it and can adversely affect sports performance (Oliva \& Hernandez-Pozo, 2009). In addition, anxiety has been considered as a physiological advantage that prepares the body for exercise, making energy available for the first moment of the competition (Fry, Schilling, Fleck, \& Kraemer, 2011).

In sports, it has been defined with respect to the stability in the time of the symptom or characteristic in people (state or trait). The transient emotional condition of the human being, characterized by subjective feelings of tension and apprehension, as well as by an overactivity of the autonomic nervous system that can change over time and fluctuate in intensity is defined as state anxiety (Spielberger, Gorsuch, \& Lushene, 1982). Whereas, the relatively stable anxiety propensity that differentiates individuals in the tendency to perceive situations as threatening, which would increase anxiety levels is called trait anxiety (Spielberger et al., 1982). Following this classification, some studies have focused on the anxiety regarding its activation in and out judo competitions (state), and how it is a part of personality that affects how the athlete behave (trait) (Sanıglu, Ulker, \& Tanıs, 2017; Papacosta, Nassis, \& Gleeson, 2016).

Anger has been defined as an unpleasant and more basic emotion than hostility and aggressiveness (Spielberger et al., 1985). It is considered a negative and destructive emotion that may be related to feelings of sadness, angst, rage and fury (Modrcin-McCarthy, Pullen, Barnes, \& Alpert, 1998). Anger is an emotional component, mainly composed of intense emotions (fury), which is preceded by a physiological neurochemical activation, as well as a subjective experience of sensations and different types of coping and expression, which can vary considering the nature of the situation and the intensity of the element that produces the emotional control that has the subject of cultural and social factors and the presence of mental disorders (Benézech, 2016). Anxiety and anger can be studied as a personality trait, as well as a transient emotional state (Fernández et al., 2019; Spielberger, et al., 1985).

In its expression, anger can take many forms such as violence, self-inflicted injuries, and physical and verbal aggression, among others; these types of aggressions generated by anger are commonly used in sports, but not necessarily with the same results or motivation. In contact and combat sports, it has been suggested that before a competition, individuals may present anger states (Salvador et al., 2003), which are influenced by biological variables that include neurological and endocrine mechanisms (Parmigiani et al., 2009). Information on the effect of anger in sports is contradictory since it may appear in relation to victory or defeat (Robazza \& Bortoli, 2003); in pre-competition, it is considered negative, so intervention programs try to improve athletic performance seeking to reduce this emotional state (Loehr, 1982). It can be considered positive because a low intensity of anger can help the athlete's performance (Proios, 2012), for example, in fighting sports, the fighter can use anger to bring more energy to the movements, considering this as a tactical advantage. The use of low 
levels of anger can be understood as an important component in physical contact sports, where it can increase the intensity, but not the risk of attacking others (Olivia \& Hernández-Pozo, 2009).

Judo requires a non-cyclical and intermittent physical effort, a melee fight by two athletes, where the goal is to beat the opponent before the time ends either by throwing him to the ground or by immobilizing him (García et al., 2008). As a sport, training and competence have similar technical and mechanical stress, but the second leads to a state of different physiological demands (Serrano, Salvador, González-Bono, Sanchis, \& Suay, 2001). In addition, the stressful potential of the competitions, age, experience, and training process, in the end, increase the number of implicit psychological demands to the sports modality (García et al., 2008).

Different studies have used the competitions as models to explore the emotional activation produced by its different moments, such as training (Salvador et al., 2003) and competition intervals (Salvador et al., 1999), to observe the result (Salvador et al., 1999). In sports like judo, one of the difficulties that apparently arises with this type of study is the impossibility to control the variables completely. However, this does not prevent the sports confrontations from being considered as reliable to obtain the results of the emotional measures, especially those related to aggression (Pesce et al., 2015).

Studies have found that the closer a competition is, the anger levels measured in questionnaires are higher (Pesce et al., 2013; Pesce et al., 2015). After the competition, the scores on the rage scale (STAXI) were higher in the athletes who won, in comparison to those who lost in an official competence, and as soon as they were restored 30 minutes after the competence.

Considering the above, it is possible to conclude that aggression is a sports activity phenomenon related, which can be understood as a display form with different levels of anxiety and anger among winning and losing athletes in different sports, such as judo. The present research aimed to evaluate the effect of winning or losing in a judo fight in the levels of anger and anxiety in male regional judo athletes, regularly linked to the Paraense Federation of Judo, Brazil, before and after competitions, as well as the correlations between total strikes and the different anger and anxiety scales evaluated in the three moments of the research.

\section{Method}

\section{Participants}

Twelve regional judo male athletes, regularly linked to the Paraense Federation of Judo, Brazil, who had a competitive experience of at least five years, were properly ranked, and officially authorized by the Federation were selected. Regarding the technical capacity, all the athletes presented at least the purple belt. People with any evidence of cardiovascular disease, a history of endocrine disorders or hypertension, or even those who used steroid-based drugs were excluded.

\section{Instruments}

\section{State-Trait Anger Expression Inventory} (Spielberger \& Biaggio, 1992). In this self-report inventory, anger is defined as a primitive emotion that does not need an attitudinal or cognitive component; it is only a behavioral expression, different from hostility. The STAXI is composed of eight subscales, with a Cronbach's alpha between 0.69 and 0.88 (Thadeu \& Ferreira, 2013): "transitory state of anger at the time of application of the tests (0.86)," trait (0.87) "Stable chronic anger". Temperament: "trait's subscale indicates the chronic tendency to anger"; in addition, Allport (1961; quoted by Izquierdo, 2002) defined it as:

that which characterizes the emotional nature

of an individual; includes the susceptibility to 
emotional stimulation, the force and speed with which the responses, the state and its fluctuations in intensity are accustomed to produce, and the phenomena are characterized as depending on the constitutional structure and the inheritance.

Reaction: "trait's subscale indicates the tendency to react with anger in situations of ego-threat and self-esteem;" anger out (0.82): "tendency to attack others or the environment;" anger in (0.73): "unconscious tendency to blame - can lead to depression;" control of anger (0.79): "conscious tendency to control anger, suppress it," and expression: "global measure of anger, taking into account the three previous scales;" STAXI was validated for its use in Brazil (Azevedo, Wang, Goulart, Lotufo, \& Benseñor, 2010; Spielberger \& Biaggio, 1992) and has also been widely used to assess anger in sports.

The Trait-State Anxiety Inventory (STAI) was designed by Spielberg, Gorsuch and Lushene in 1970 and validated for its application in Brazil by Spielberg, Biaggio and Natalício (1979). STAI is a self-application scale that allows you to assess anxiety, both as a state and as a trait. The questionnaire consists of 40 questions, placed in terms of intensity (from almost never to usually). The questions are divided into two scales: the state-anxiety understood as an experience at the time, a sense of insecurity, helplessness as perceived harm that can lead to worrying or fleeing and avoiding, and another scale of anxiety-trait measures the tendency to perceive stressful situations as dangerous and threatening, and respond to different situations with different intensity. In its refined version, it uses 13 for the state and 12 for the trait (Kaipper, Chachamovich, Hidalgo, Da Silva Torres, \& Caumo, 2010).

To count the number of strikes in the encounter, we recorded (Sony DCR-Sx20) and later analyzed them, using the ethogram proposed by Miarka in 2014, who defined "hits", effective or not, as the technique applied in standing combat with arms, legs or hips. The filming was done with full view of the fighters, as well as making a fight time control.

\section{Procedure}

All measurements were made in a judo competition with the exception of the baseline, which was taken at the training site and out of competition (figure 1), before completing the anamneses and the terms of consent. The full versions of the STAXI 2 and STAI tests were applied at least three weeks before competition. After the baseline's measures were taken, the athletes were accompanied to a competitive event in the city of Paragominas, where the second and third measurements were taken, the first one, half an hour before the fight, and the second, after the fight was concluded. These evaluations used the refined versions. In the case of STAXI, 4 scales and in the case of STAI, 25 questions (Kaipper et al., 2010).

After the competition results, the fighters were separated into two groups, winners (8) and losers (4), and the anger and anxiety scales were applied. The fights were filmed to count the number of strikes; right after the fight, the instruments were re-applied.

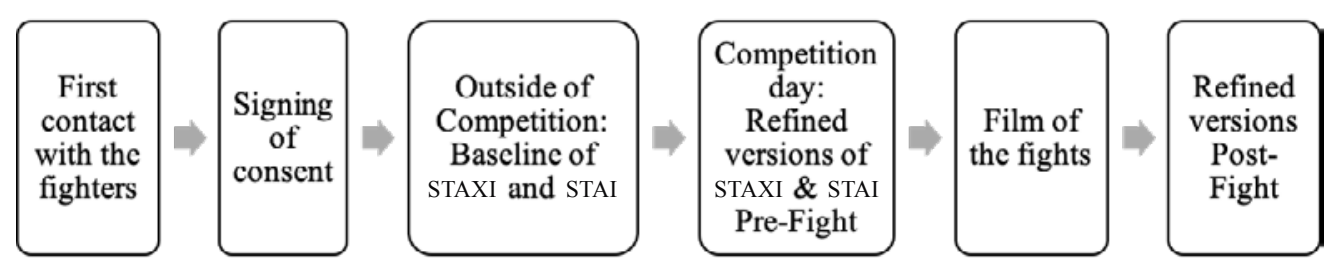

Figure 1. Data collection procedure 


\section{Ethical care}

Research Ethics Committee of the Federal University of Pará Opinion no. 1622308. Confirmation of participation in the study was determined by the signing of a consent form prepared for this purpose.

\section{Data analysis}

For the data analysis, we used the SigmaStat 3.5 software (Systac Software Inc.). The fight data was summarized in the number of strikes, adding the strikes of hip, feet and pitch. Data used for analysis showed normality when statistically analyzed. In order to evaluate the effect of the result of the fight (win/lose) on the different behavioral measures pre-fight and post-fight, a one-way analysis of variance (one-way ANOVA) was done, where the factor was related to the result (winners vs. losers). In addition, an ANOVA for repeated measures was performed that allowed to evaluate the data in relation to time (basal, pre-, and post), and to know the possible differences between and intragroup.

Finally, a Pearson correlation was performed to know the relation between the measured compo- nents (STAXI-STAI-Number of Strikes). In the case of the measures evaluated by the refined versions, the values were normalized with a simple three rule in relation to the total score in the baseline evaluations. A $p<0.05$ was used for all cases.

\section{Results}

\section{Effect of Winning/Losing in Anger and Anxiety}

The analysis of variance of a factor (one-way ANOVA) performed to evaluate the effect of the result on the STAI and STAXI scales revealed that there was no statistically significant difference for most scales. However, the same analysis showed (figure 2) a statistically significant difference in basal anger out $(\mathrm{F}[1: 10]=5.955, \mathrm{p}=0.035, \mathrm{VD}=$ $1,43)$. The subjects who were going to lose had a higher level of anger than those who won.

Although the difference was not significant, the analysis also revealed a trend with respect to the baseline state of the STAI basal $(\mathrm{F}[1: 10]=4,390$, $\mathrm{p}=0.063, \mathrm{VD}=1,43)$, which refers to a higher anxiety state in the winning subjects.

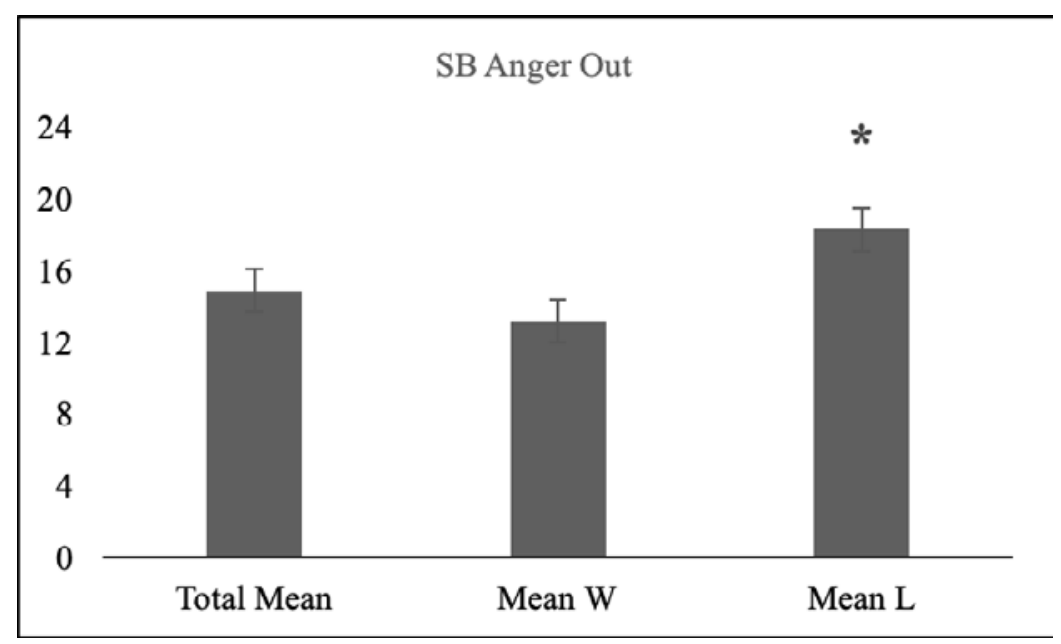

Figure 2.

STAXI basal anger out, total mean of the sample, mean of the winners (Mean W) and the losers (Mean L); *, >; where $\mathrm{W}$ - Winners of the fight; $\mathrm{L}$ - losers of the fight; SB - STAXI Basal; (One-way Anova, $\mathrm{P}<0,05$ ). 


\section{Differences between Groups and Inter-} Groups over Time (Winners and Losers)

Regarding the differences between groups and inter-groups, the ANOVA for repeated measures showed that in STAXI, there were no statistically significant differences between winners and losers (figure 3), for any of the scales evaluated in the three moments of the research.

STAI had statistically significant differences between the winners and losers (repeated measures ANOVA), both in the state $(\mathrm{F}[1,10]=5.655, \mathrm{p}=$ $0.039)$ and in the trait $(\mathrm{F}[1,10]=8.794, \mathrm{p}=0.014)$. The losers presented higher levels of anxiety than the winners did (figure 4). In addition, there was also a difference in anxiety levels over time, where the trait and the pre- and post-fight state were higher than in baseline measurements (for losers).

\section{Correlations between Total Number of Strikes, Anger and Anxiety}

After the above analysis, the Pearson correlation was made, using the data for baseline anger and anxiety (figure 5), pre-fight (figure 6), and post-fight (figure 7), along with the total number of strikes, of the three competition times. There were different positive and negative correlations $(p<0.05)$ between the different values of each moment and between moments.

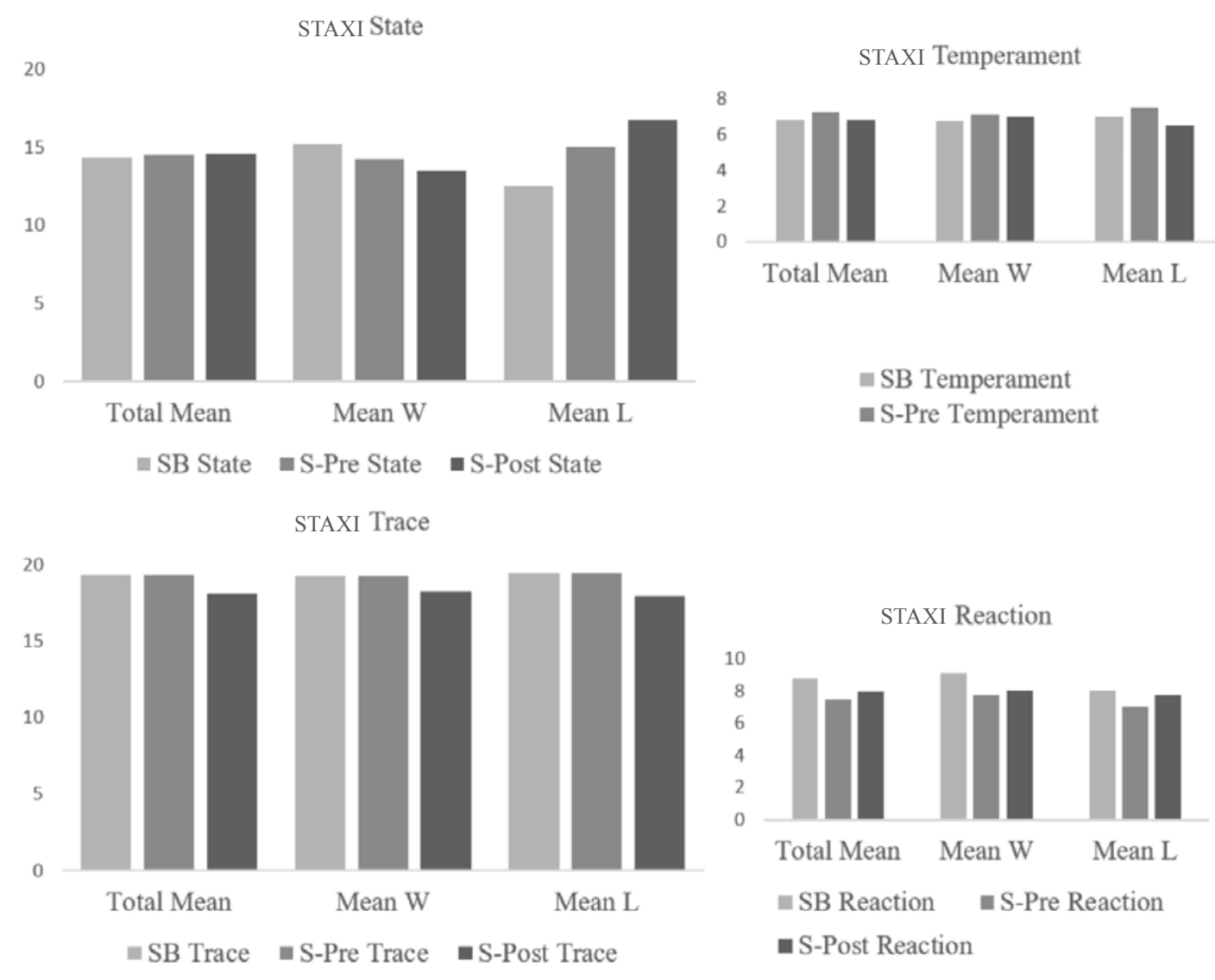

Figure 3.

STAXI Trait, State, Temperament and Reaction through investigation, total means, Mean of Winners (Mean W), Mean of Losers Mean (Mean L), basal, pre e post fight, where SB - STAXI Basal; S-Pre - STAXI Pre fight; S-Pos - STAXI Post fight. 


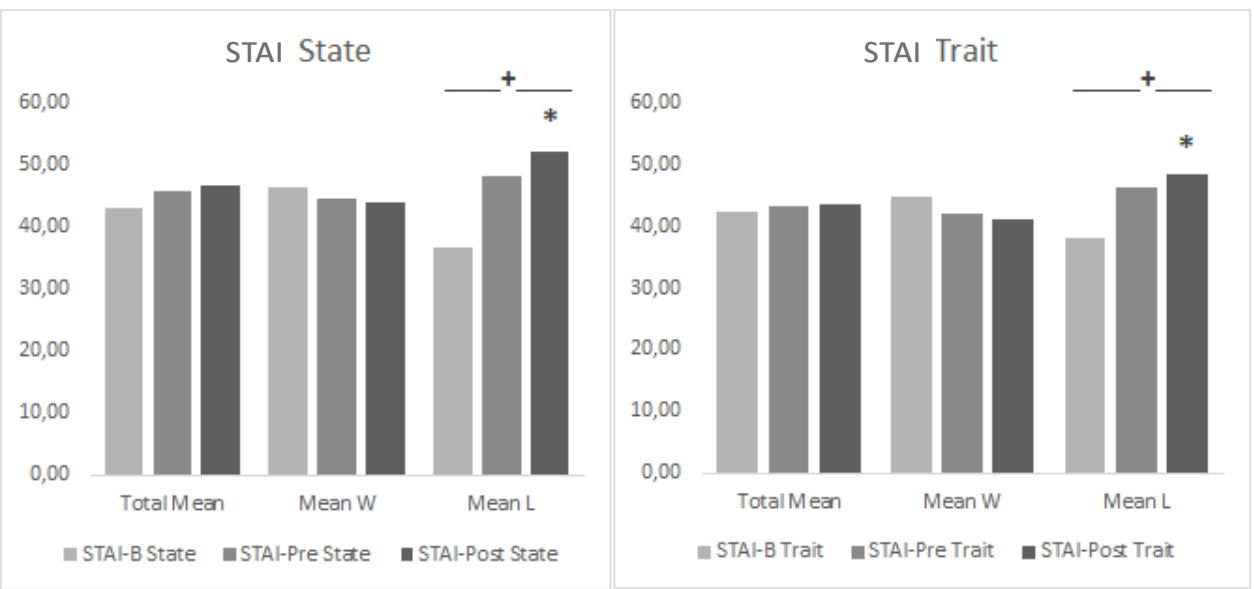

Figure 4.

STAI State and Trait through investigation, total means, Mean of Winners (Mean W), Mean of Losers Mean (Mean L), basal, pre e post fight, where $*>$; and $+>$. ANOVA for repeated measures $(\mathrm{p}<0.05)$.

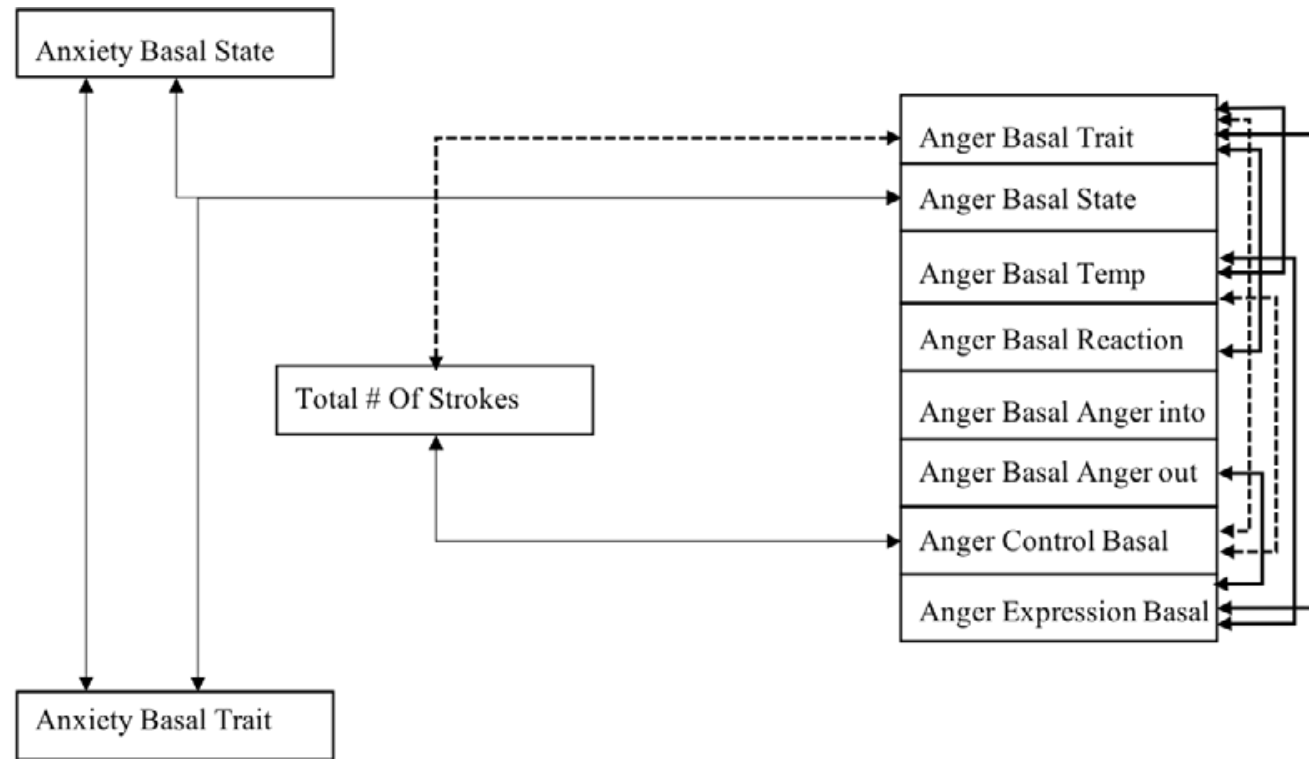

Figure 5. Positive and negative correlations between

Total number of strikes and basal anxiety and anger $(\mathrm{p}<0.05) .(\rightarrow)$ Positive correlations; $(--->)$ negative correlations.

In the baseline measurements, we found correlations with the total number of strikes and anger, but not with anxiety, trait anger, and the number of strikes negatively correlated $(r=-066, p=0.019)$. However, the basal control positively correlated with the number of strikes $(r=0.625, p=0.30)$. The same was also found between control and trait $(\mathrm{r}=-0.581, \mathrm{p}=0.048)$, and positively with the temperament $(\mathrm{r}=0.812, \mathrm{p}=0.001)$, the reaction $(r=0.792, p=0.002)$, and the expression $(\mathrm{r}=0.614, \mathrm{p}=0.034)$. A positive correlation was also found between the baseline states of STAXI and STAI $(\mathrm{r}=0.852, \mathrm{p}=0.000)$ and STAI trait $(\mathrm{r}=$ $0.868, \mathrm{p}=0.000)$. 


\section{Correlations Results: STAI and STAXI Pre-Fight}

Regarding the pre-fight results and the total number of strikes, a negative correlation with temperament $(\mathrm{r}=-0.596, \mathrm{p}=0.41)$ was identified, plus temperament positively correlated with the pre-fight anger trait $(\mathrm{r}=0.743, \mathrm{p}=0.006)$ with post-fight trait $(r=0.718, p=0.009)$, and temperament $(r=0.803, p=0.002)$, and with state pretrait $(\mathrm{r}=0.642, \mathrm{p}=0,24 \& \mathrm{r}=0.743, \mathrm{p}=0.024$, respectively) and post-fight $(\mathrm{r}=0.709, \mathrm{p}=0.010$ and $\mathrm{r}=0.638, \mathrm{p}=0.026$, respectively) of the STAI.

The trait of pre-fight anger positively correlates with pre-fight reaction $(\mathrm{r}=0.702, \mathrm{p}=0.001)$, the trait $(\mathrm{r}=0.861, \mathrm{p}=0.000)$, the temperament $(\mathrm{r}=0.812, \mathrm{p}=0.001)$, and the reaction $(\mathrm{r}=0.727$, $\mathrm{p}=0.007)$ post-fighting, and STAI with the anxiety state, trait $(r=0.618, p=0.032 \& r=0.703$, $\mathrm{p}=0.011$, respectively), and post-fight $(\mathrm{r}=0.662$, $\mathrm{p}=0.019 \& \mathrm{r}=0.616, \mathrm{p}=0.33$, respectively).

\section{Correlations Post-Fight: Results of STAI and STAXI}

Finally, the post-fight results had correlations with each other. In addition to those previously mentioned, in this case no correlation was found in relation to the number of strikes.

Anger trait in this case correlated with the temperament $(r=0.883, p=0.000)$ and the reaction $(\mathrm{r}=0.907, \mathrm{p}=0.000)$, and STAI with the state $(\mathrm{r}=0.684, \mathrm{p}=0.014)$ and the trait $(\mathrm{R}=0.756$, $\mathrm{p}=0.004)$. The temperament correlated positively with the reaction $(r=0.687, p=0.014)$ and the state $(r=0.637, p=0.026)$ and trait $(r=0.636$, $\mathrm{p}=0.026)$ of STAI, and the reaction correlated with STAI's trait $(r=0.581, p=0.047)$.

\section{Discussion and Conclusions}

There were differences between the groups of winners and losers in relation to anxiety, but not to anger, both the state and the trait varied in the groups regarding time. The final post-fight anxiety was higher in comparison to the basal and pre-fight; the change in strikes was associated with a temporal perception of different questions found on the scale. In the case of the winners, the pre-competitive anxiety was higher than that post-fight. The low pre-fight anxiety and the levels of anger have been associated with an increase in energy and, in certain amounts, can even be an advantage to increase the confidence of the athletes, as well as to improve

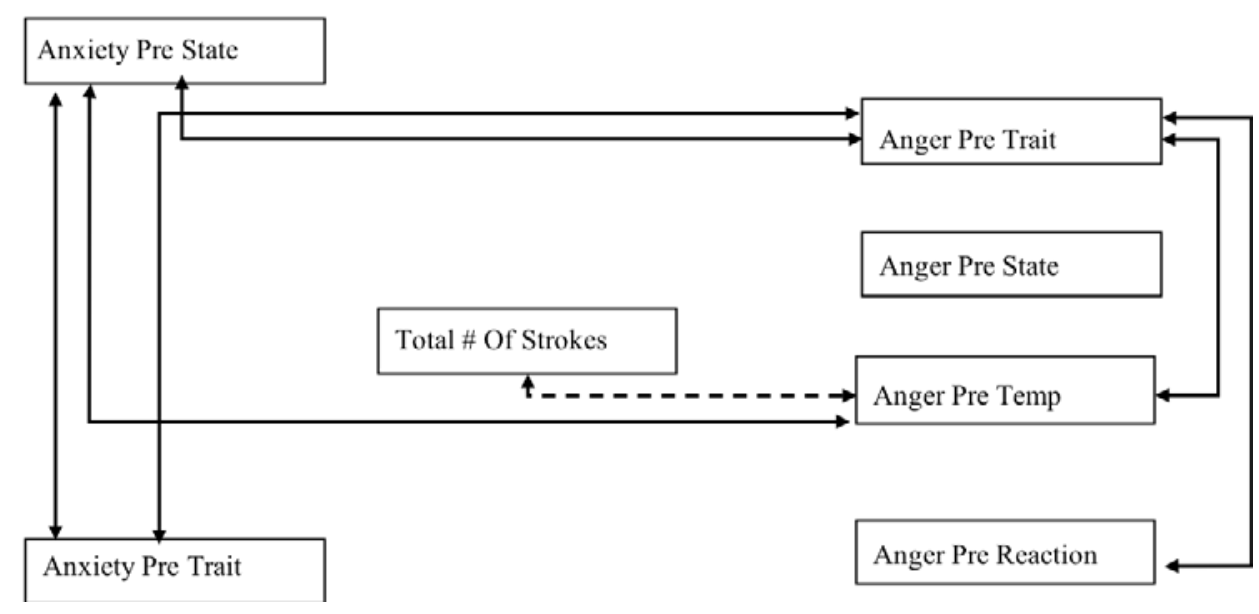

Figure 6. Positive and negative correlations between

Total number of strikes and pre-fight anxiety and anger $(\mathrm{p}<0.05) .(\rightarrow)$ Positive correlations; $(--->)$ negative correlations. 


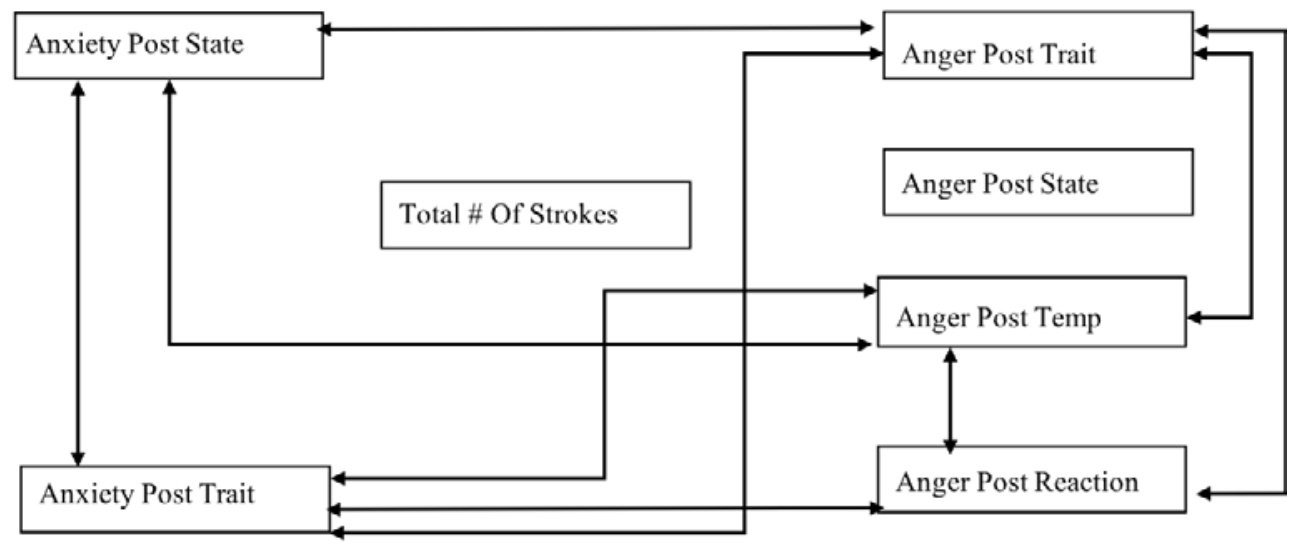

Figure 7. Positive and negative correlations between

Total number of strikes and post-fight anxiety and anger $(\mathrm{p}<0.05) .(\rightarrow)$ Positive correlations; $(--->)$ negative correlations.

the decisions made by judokas (Lane et al., 2010; Valente, Moreira, \& Zanetti, 2012; Vaughan, Laborde, \& McConville, 2019).

These data corroborate the study carried out by Gea García, Alonso Roque, Ureña Ortín, and Garcés de los Fayos Ruiz (2016), the increase in anxiety, called tension in the research, increased in intensity previously and in the confrontations; however, anger decreased in intensity. This increase in anxiety has been reported as an advantage for competitions by different studies that include both individual or team sports (Arruda, Aoki, Paludo, \& Moreira, 2017; Cintineo \& Arent, 2019; Fry et al, 2011; Radzi, Yusuf, Amir, \& Mansor, 2018). For it to be effective, the athlete has to be prepared to cope with the stress response (Papacosta et al., 2016).

Correlations evidenced the relationship between the scales, the measured affections, the number of strikes, anger, and anxiety. In relation to the scales, these correlations were related to the internal consistency of the tests, where different questions evaluate different components, as in the case of STAXI- 2 and its 8 scales. In relation to the STAI, which are two different scales for state and trait, this correlation was associated with an anxious reaction in everyday situations due to the emotional component that remains over time, a way to actually confirm the anxious response, was the correlation found between the basal line and the states in the three moments of the competition. A trait of anxiety affects the way in which people usually react to stressful situations, in the case of sportsmen competition.

Finally, in what refers to correlations, anger correlated with the number of strikes, but anxiety did not. The correlations were mostly negative, where the trait and the high temperament meant a lower number of strikes. Although, the high control correlated with a greater number of strikes, considering that anger allows to dispose of a boost of perceived energy levels (Chhabra, Vyas, Chatterjee, \& Voß, 2016; Moons, Eisenberger, \& Taylor, 2010), lack of self-control could end in a punishment related to the breaking of the rules (Ruiz \& Hanin, 2011).

In the case of the relation between anger and anxiety, the correlations outside the fighting situation were different than in the moments of struggle. The anger state and the baseline STAI trait and state correlated, but they did not correlate with the STAXI trait, in the pre- and post-fight; the two anxiety scales correlated with the trait. In addition to the states/ traits correlations, a positive correlation between temperament and anxiety (state/trait) was found at all moments of the competition, something similar to what was found by Kuuseok and Ratassepp 
(2001; quoted by Carretero, Moreno-Murcia, Ponce, González \& Gimeno, 2012), which is explained by the convergence of affections in relation to temperament, so the temperament that is expressed as a baseline in the subject predisposes to a reaction above this in a stress situation, here placed the fight and its outcome.

In relation to table 1 , the presence of anger and anxiety reveals a convergence of the two types of aggression (defensive and offensive). Firstly, in the case of the defensive aggression, the tendency of the state to be greater in the winners allowed us to observe a greater presence of the defensive. In the case of the offensive, especially the intra-specific one reflected in higher levels of anger, which were the results found in losers. Although not on the same levels, when analyzing the set of fighters, this allowed observing the presence of the two types of aggression, mainly in the amounts of positive correlations found between the two affections since they are not disconnected responses but increase and decrease together. Changes in mood states are related to the type of activity (Gea García et al, 2016). In conclusion, two types of aggression can be found with different objects, equal triggering stimuli, similar behaviors with different effects, and an opposite result. In the case of the winners, a type of defensive aggression that seeks the defense of the individual, in addition to obtaining a resource, uses the sports medium as a display with higher levels of anxiety. In the offenders' aggressive offense, seeking the attack of the opponent and obtaining recourse, aggression is supported by the display (the combat) and moved to a greater extent by anger (table 1).

The results of the present study show a statistically significant difference between winners and losers in relation to anger, but not anxiety, specifically with regard to the baseline anger out. Fighters who presented the highest levels of this type of anger lost the fight, while the winners presented a lower level. Anger can increase when approaching a sporting event, the study carried out by Pesce et al. (2013), moreover, correlated with an increase in IL-1B levels, a biomarker of anger. Similarly, Cisneros-Fonseca, Morales-Toboso, and Fomenech-Morales (2015) found in a group of baseball pitchers that anger worsened performance at the time of the sport, which was related to a loss of concentration of the athletes. However, according to Robazza and Bortoli (2003) anger appearance is not only related to loss, as it can also be presented in the victory. Although, in this research, it was only found in the losers.

Based on the above, it can be concluded that the responses associated with anger had a physical component, whereas anxiety was more cognitive. That justifies the increase in anxiety inventories and its lack of correlation with the number of strikes.

In the comparison between winners and losers, the expression of anger was greater in losers than in winners. The correlation analysis showed that the expression of the aggression was positively related to the control of anger and negatively related to its basal expression, given that there is no relation with the data in the post-fight.

As conclusions, we found that anger seemed to be an important component of the fight's outcome, and its levels are necessary for performance, but are likely to impair at higher levels. Also, in relation to the strikes and to the anger and anxiety components, the aggressiveness in the fight seems to be dissociated from the emotional indicators in the post-fight, so that there is no correlation between the number of strikes and emotional measures in the second moment. Finally, losing the fight alters anxiety, but not anger probably because the latter is more demanding of reflection on the part of the subject.

\section{Limitations and Future Research Directions}

There are some methodological limitations that have to be considered when interpreting the 
results. The first one is related to the kind of psychological tests used; they were self-reported, and even though they offer a reliable way to evaluate both anger and anxiety, other measures, such as physiological ones, could confirm the higher or lower results in the scales.

Another limitation found was related to the comparation between the general population and the sample used in the research since when comparing both, the fighters showed higher levels of anger that those of the Brazilian standards of the STAXI, so the fact that this research did not have a non-practice sports group, prevented from issuing a statement with statistical significance of the differences between these two types of groups.

Considering the limitations, as future research, we recommend including physiological assessment of cortisol and testosterone, as well as non-competitive and non-practice sports groups.

\section{References}

Alcazar-Córcoles, M. Á., Verdejo-García, A., Bouso-Saiz, J. C., \& Bezos-Saldaña, L. (2010). Neuropsicología de la agresión impulsiva. Revista de Neurología, 50(5), 291-299.

Arias-Carrión, O., Stamelou, M., Murillo-Rodríguez, E., Menéndez-González, M., \& Pöppel, E. (2010). Dopaminergic reward system: A short integrative review. International Archives of Medicine, 3(1), 24. Doi: https://doi. org/10.1186/1755-7682-3-24

Arruda, A. F., Aoki, M. S., Paludo, A. C., \& Moreira, A. (2017). Salivary steroid response and competitive anxiety in elite basketball players: Effect of opponent level. Physiology \& Behavior, 177, 291-296. Doi: https://doi. org/10.1016/j.physbeh.2017.05.017

Azevedo, F. B. D., Wang, Y. P., Goulart, A. C., Lotufo, P. A., \& Benseñor, I. M. (2010). Application of the Spielberger's State-Trait Anger Expression Inventory in clinical patients. Arquivos de
Neuro-psiquiatria, 68(2), 231-234. Doi: http:// dx.doi.org/10.1590/S0004-282X2010000200015

Bénézech, M. (2016). La colère chez les auteurs de violence: une dimension fondamentale en psychiatrie légale. L'Évolution Psychiatrique, 81(4), 881-889. Doi: https://doi.org/10.1016/j. evopsy.2015.12.007

Blank, D. A., Ruckstuhl, K., \& Yang, W. (2015). Seasonal dynamics of agonistic displays in territorial and non-territorial males of goitered gazelle. Zoology, 118(1), 63-68. Doi: https:// doi.org/10.1016/j.zool.2014.08.004

Carretero, C. M., Moreno-Murcia, J. A., Ponce, I. G., González, J. J. P., \& Gimeno, E. M. C. (2012). Precompetitive state anxiety in judo. Revista de Artes Marciales Asiáticas, 7(1), 26-43.

Chhabra, P., Vyas, G., Chatterjee, J., \& Voß, S. H. (2016, September). An automatic system for recognition and assessment of anger using adaptive boost. 2016 International Conference on Micro-Electronics and Telecommunication Engineering (ICMETE) (pp. 151-154). Doi: https:// doi.org/ 10.1109/ICMETE.2016.89

Cintineo, H. P., \& Arent, S. M. (2019). Anticipatory salivary cortisol and state anxiety before competition predict match outcome in division I collegiate wrestlers. The Journal of Strength \& Conditioning Research, 33(11), 2905-2908. Doi: https://doi.org/10.1519/JSC.0000000000003376

Cisneros-Fonseca, M. E., Morales-Toboso, M., \& Domenech-Morales, Á. (2015). Caracterización de los efectos del enojo en lanzadores de béisbol categoría 13-15 años (original). Revista cientifica Olimpia, 12(37), 11-20. Recuperado a partir de https://revistas.udg.co.cu/index.php/ olimpia/article/view/1360

Fernández, M. M., Bello, F. D., Barreto, L. B. M., Brito, C. J., Miarka, B., \& Díaz-De-Durana, A. L. (2019). State-trait anxiety and reduced emotional intelligence in combat sport athletes of different genders and competitive levels. Journal of Physical Education and Sport, 19, 363. Doi: https://doi.org/10.7752/jpes.2019.s2054 
Fry, A. C., Schilling, B. K., Fleck, S. J., \& Kraemer, W. J. (2011). Relationships between competitive wrestling success and neuroendocrine responses. The Journal of Strength \& Conditioning Research, 25(1), 40-45. Doi: https://doi.org/10.1519/ JSC.0b013e3181fef62f

García, R. H., Zafra, A. O., \& Toro, E. O. (2008). Ansiedad y autoconfianza de jóvenes judokas en situaciones competitivas de alta presión. Análise Psicológica, 26(4), 689-696.

Gea García, G. M., Alonso Roque, J. I., Ureña Ortín, N., \& Garcés de los Fayos Ruíz, E. (2016). Incidencia de los juegos deportivos de oposición sobre los estados de ánimo en universitarios. Revista de Psicología del Deporte, 25(2), 237-244.

Geniole, S. N., Bird, B. M., Ruddick, E. L., \& Carré, J. M. (2017). Effects of competition outcome on testosterone concentrations in humans: An updated meta-analysis. Hormones and Behavior, 92, 37-50. Doi. https://doi.org/10.1016/j.yhbeh.2016.10.002

Gómez, R. P., Sánchez, J. C. J., Sánchez, M. D. P. M., \& Amarillo, P. J. (2016). El poder explicativo de la ansiedad en los estados de ánimo de deportistas españoles. Retos: Nuevas Tendencias en Educación Física, Deporte y Recreación, (30), 207-210.

Huber, R., Bannasch, D., \& Brennan, P. (2011). Aggression (Vol. 75). San Diego: Elsevier.

Izquierdo, A. M. (2002). Temperamento, carácter, personalidad. Una aproxímacíon a su concepto e interacción. Revista Complutense de Educación, 13(2), 617.

Kaipper, M. B., Chachamovich, E., Hidalgo, M. P. L., Da Silva Torres, I. L., \& Caumo, W. (2010). Evaluation of the structure of Brazilian StateTrait Anxiety Inventory using a Rasch psychometric approach. Journal of Psychosomatic Research, 68(3), 223-233. Doi: https://doi. org/10.1016/j.jpsychores.2009.09.013

Lane, A. M., Devonport, T. J., Soos, I., Karsai, I., Leibinger, E., \& Hamar, P. (2010). Emotional intelligence and emotions associated with optimal and dysfunctional athletic performance. Journal of Sports Science \& Medicine, 9(3), 388.

Lehner, S. R., Rutte, C., \& Taborsky, M. (2011). Rats benefit from winner and loser effects. Ethology, 117(11), 949-960. Doi: https://doi.org/10.1111/ j.1439-0310.2011.01962.x

Loehr, J. (1982). Mental toughness training for sports: Achieving athletic excellence. New York: Plume.

Martínez-Díez, I. (2008). Comportamiento agresivo en el pez luchador de Siam (Betta splendens). Anales Universitarios de Etología, 2, 98-105.

Modrcin-McCarthy, M. A., Pullen, L., Barnes, A. F., \& Alpert, J. (1998). Childhood anger: So common, yet so misunderstood. Journal of Child and Adolescent Psychiatric Nursing, 11(2), 69-77.

Miarka, B. (2014). Modelagem das interações técnicas e táticas em atletas de judô: comparações entre categoria, nível competitivo e resultados de combates do circuito mundial de judô e dos jogos olímpicos de Londres. (Doctoral dissertation, Universidade de São Paulo, São Paulo). Doi: http://dx.doi.org/10.11606/T.39.2014. tde-29042014-174600

Montás, G. C. (2011). Perfil neurocognitivo de agresores masculinos en contextos familiares como un subtipo de la agresión generalizada ( $1^{\mathrm{a}}$ parte). Ciencia y Sociedad, 36(2).

Moons, W. G., Eisenberger, N. I., \& Taylor, S. E. (2010). Anger and fear responses to stress have different biological profiles. Brain, Behavior, and Immunity, 24(2), 215-219. Doi: https://doi. org/10.1016/j.bbi.2009.08.009

Oliva, F. J., \& Hernandez-Pozo, M. D. R. (2009). Efectos de la agresión colérica en el desempeño deportivo en deportes de contacto: una revisión empírica. Journal of Behavior, Health \& Social Issues, 1(1).

Ouergui, I., Davis, P., Houcine, N., Marzouki, H., Zaouali, M., Franchini, E., ... \& Bouhlel, E. (2016). Hormonal, physiological, and physical performance during simulated kickboxing combat: Differences between winners and losers. International Journal of Sports Physiology and 
Performance, 11(4), 425-431. Doi: https://doi. org/10.1123/ijspp.2015-0052

Papacosta, E., Nassis, G. P., \& Gleeson, M. (2016). Salivary hormones and anxiety in winners and losers of an international judo competition. Journal of Sports Sciences, 34(13), 1281-1287. Doi: https://doi.org/10.1080/02640414.2015.1111521

Parmigiani, S., Dadomo, H., Bartolomucci, A., Brain, P. F., Carbucicchio, A., Costantino, C., ... \& Volpi, R. (2009). Personality traits and endocrine response as possible asymmetry factors of agonistic outcome in karate athletes. Aggressive behavior, 35(4), 324-333. Doi: https://doi. org/10.1002/ab.20306

Paton, D., \& Caryl, P. G. (1986). Communication by agonistic displays. Behaviour, 98(1), 213-239.

Peña, M. P., \& Oreja, M. S. (2019). Estudio descriptivo de la presencia de ansiedad y motivación pre y post-competitiva en jóvenes judokas. $R e$ vista Española de Educación Física y Deportes, (426), 136-144.

Pesce, M., La Fratta, I., Ialenti, V., Patruno, A., Ferrone, A., Franceschelli, S., ... \& Felaco, M. (2015). Emotions, immunity and sport: Winner and loser athlete's profile of fighting sport. Brain, behavior, and immunity, 46, 261-269. Doi: https://doi.org/10.1016/j.bbi.2015.02.013

Pesce, M., Speranza, L., Franceschelli, S., Ialenti, V., Iezzi, I., Patruno, A., ... \& Grilli, A. (2013). Positive Correlation Between Serum Interleukin- $1 \beta$ and State Anger in Rugby Athletes. Aggressive Behavior, 39(2), 141-148. Doi: https://doi.org/10.1002/ab.21457

Proios, M. (2012). The relation between the emotion of "anger" and the cognitive processes in gymnastics athletes. International Quarterly of Sport Science, 1, 10-18.

Pulido, S., Fuentes, J. P., \& De la Vega, R. (2019). Ansiedad competitiva en judokas cadetes: diferencias en género y categoría de peso. Rui Resende Hugo Sarmento, 5(1), 21-26.

Radzi, J. A., Yusuf, S. M., Amir, N. H., \& Mansor, S. H. (2018). Relationship of pre-competition anxiety and cortisol response in individual and team sport athletes. In Saian R., Abbas M. (Eds), Proceedings of the Second International Conference on the Future of ASEAN (ICOFA) 2017-Volume 2 (pp. 719-727). Doi: https://doi. org/10.1007/978-981-10-8471-3_70

Robazza, C., \& Bortoli, L. (2003). Intensity, idiosyncratic content and functional impact of performance-related emotions in athletes. Journal of Sports Sciences, 21(3), 171-189. Doi: https:// doi.org/10.1080/0264041031000071065

Rosell, D. R., \& Siever, L. J. (2015). The neurobiology of aggression and violence. CNS Spectrums, 20(3), 254-279. Doi: https://doi.org/10.1017/ S109285291500019X

Ruiz, M. C., \& Hanin, Y. L. (2011). Perceived impact of anger on performance of skilled karate athletes. Psychology of Sport and Exercise, 12(3), 242-249. Doi: https://doi.org/10.1016/j. psychsport.2011.01.005

Salvador, A., Suay, F., Gonzalez-Bono, E., \& Serrano, M. A. (2003). Anticipatory cortisol, testosterone and psychological responses to judo competition in young men. Psychoneuroendocrinology, 28(3), 364-375. Doi: https://doi.org/10.1016/ S0306-4530(02)00028-8

Sanıoglu, A., Ulker, M., \& Tanıs, Z. S. (2017). The effect of trait anxiety on success in individual athletes. Turkish Journal of Sport and Exercise, 19(2), 289-295. Doi: https://doi.org/10.15314/ tsed.339422

Salvador, A., Suay, F., Martinez-Sanchis, S., Simon, V. M., \& Brain, P. F. (1999). Correlating testosterone and fighting in male participants in judo contests. Physiology \& Behavior, 68(1), 205-209. Doi: https://doi.org/10.1016/S00319384(99)00168-7

Sebastián, F. (2013). La ética del deporte en el contexto actual de la filosofia, desde la aportación de la modernidad crítica. (Doctoral dissertation, Universitat de Valencia, España).

Serrano, M. A., Salvador, A., González-Bono, E., Sanchís, C., \& Suay, F. (2001). Relationships 
between recall of perceived exertion and blood lactate concentration in a judo competition. Perceptual and Motor Skills, 92(3_suppl), 1139-1148.

Schiphof-Godart, L., Roelands, B., \& Hettinga, F. J. (2018). Drive in sports: How mental fatigue affects endurance performance. Frontiers in Psychology, 9, 1383. Doi: https://doi.org/10.3389/ fpsyg.2018.01383

Siever, L. J. (2008). Neurobiology of aggression and violence. American Journal of Psychiatry, 165(4), 429-442.

Spielberger, C. D., \& Biaggio, A. (1992). Manual do STAXI. São Paulo: Vetor.

Spielberger, C. D., Biaggio, A., \& Natalicio, L. F. (1980). Manual do IDATE. Rio de Janeiro: CEPA.

Spielberger, C. D., Gorsuch, R. L., \& Lushene, R. (1982). Manual del cuestionario de ansiedad estado/rasgo (STAI). Madrid: TEA Ediciones.

Spielberg, C., Gorsuch, R. L., \& Lushene, R. E. (1970). The state-trait anxiety inventory. Palo Alto.

Spielberger, C., Johnson, E., Russell, S. Crane, R., Jacobs, G., \& Worden, T. (1985). The experience and expression of anger: Construction and validation of an anger expression scale. In M. Chesney \& R. Rosenman (Eds.), Anger and hostility in cardiovascular and behavioral disorders (pp. 5-30). Hemisphere: McGraw-Hill.

Strahler, J., Berndt, C., Kirschbaum, C., \& Rohleder, N. (2010). Aging diurnal rhythms and chronic stress: Distinct alteration of diurnal rhythmicity of salivary $\alpha$-amylase and cortisol. Biological Psychology, 84(2), 248-256. Doi: https://doi. org/10.1016/j.biopsycho.2010.01.019

Takahashi, A., Shimamoto, A., Boyson, C. O., DeBold, J. F., \& Miczek, K. A. (2010). GABAB receptor modulation of serotonin neurons in the dorsal raphe nucleus and escalation of aggression in mice. Journal of Neuroscience, 30(35), 11771-11780. Doi: https://doi.org/10.1523/ JNEUROSCI.1814-10.2010
Thadeu, S. H., \& Ferreira, M. C. (2013). A validade da avaliação psicológica em um processo seletivo na área de segurança pública. Revista Iberoamericana de Diagnóstico y Evaluación-e Avaliação Psicológica, 2(36), 117-145.

Trannoy, S., \& Kravitz, E. A. (2017). Strategy changes in subsequent fights as consequences of winning and losing in fruit fly fights. Fly, 11(2), 129138. Doi: https://doi.org/10.1080/19336934.2 016.1259041

Valente, D., Moreira, A. B., \& Ztanetti, M. C. (2012) Levels and symptoms of precompetitive stress in a judo team in 2011 and 2012 in a regional championship. IV Seminar on Sport Psychology and Human Motricity, I National Congress of Human Motricity Psychology, Sport, Recreation and Dance.

Vaughan, R., Laborde, S., \& McConville, C. (2019). The effect of athletic expertise and trait emotional intelligence on decision-making. European journal of sport science, 19(2), 225-233. Doi: https://doi.org/10.1080/17461391.2018 .1510037

Verona, E., Patrick, C. J., Curtin, J. J., Bradley, M. M., \& Lang, P. J. (2004). Psychopathy and physiological response to emotionally evocative sounds. Journal of Abnormal Psychology, 113(1), 99. Doi: https://doi.org/10.1037/0021843X.113.1.99

Von Borries, A. K. L., Volman, I., de Bruijn, E. R. A., Bulten, B. H., Verkes, R. J., \& Roelofs, K. (2012). Psychopaths lack the automatic avoidance of social threat: Relation to instrumental aggression. Psychiatry Research, 200(2), 761-766. Doi: https://doi.org/10.1016/j.psychres.2012.06.026

Zhou, T., Zhu, H., Fan, Z., Wang, F., Chen, Y., Liang, H., ... \& Wang, Z. (2017). History of winning remodels thalamo-PFC circuit to reinforce social dominance. Science, 357(6347), 162-168. Doi: https://doi.org/10.1126/science.aak9726 
Complementary Archive

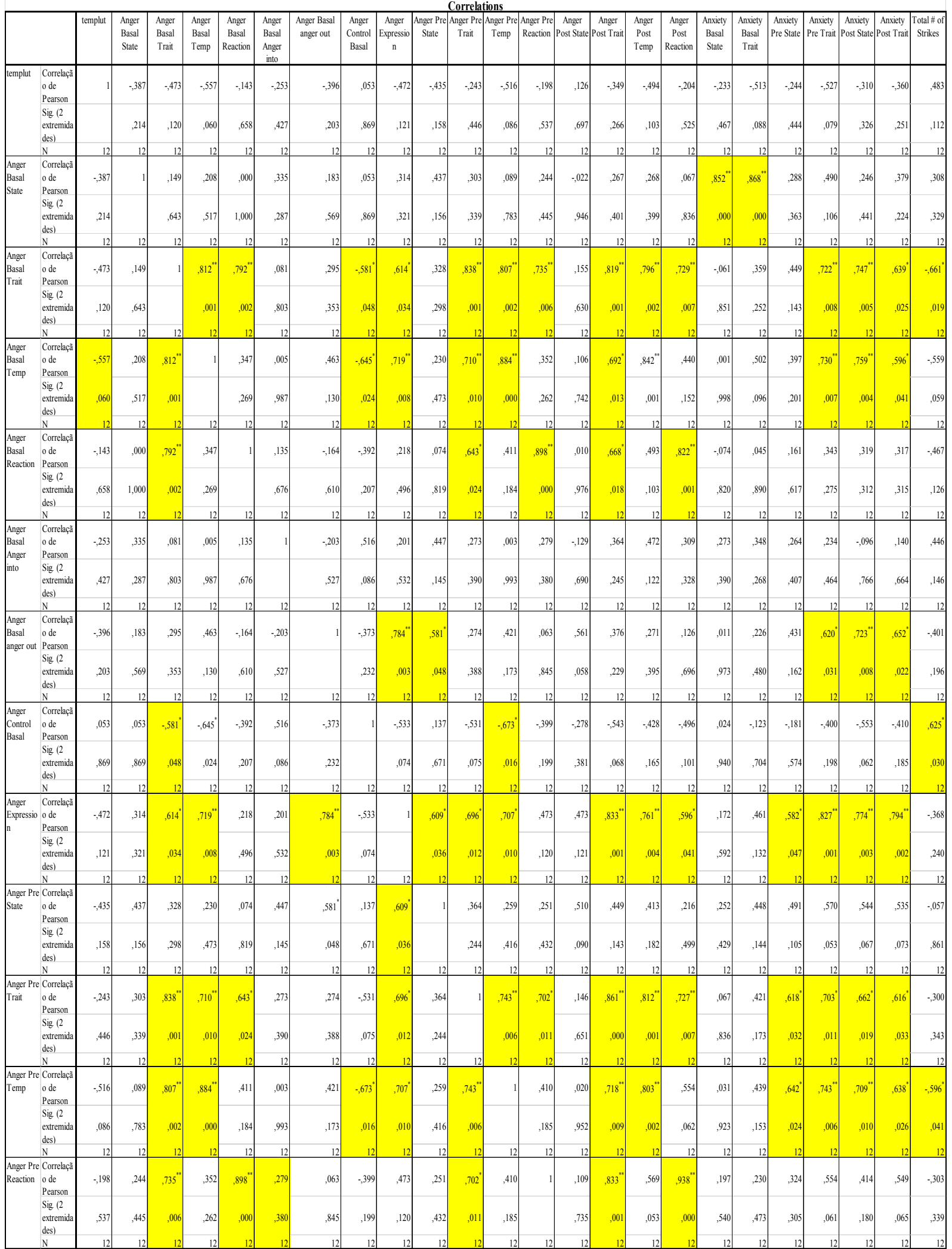


Héctor Andrés Páez-Ardila, Ítalo Sergio Lopes Campos, fmauri Gouveia Jr.

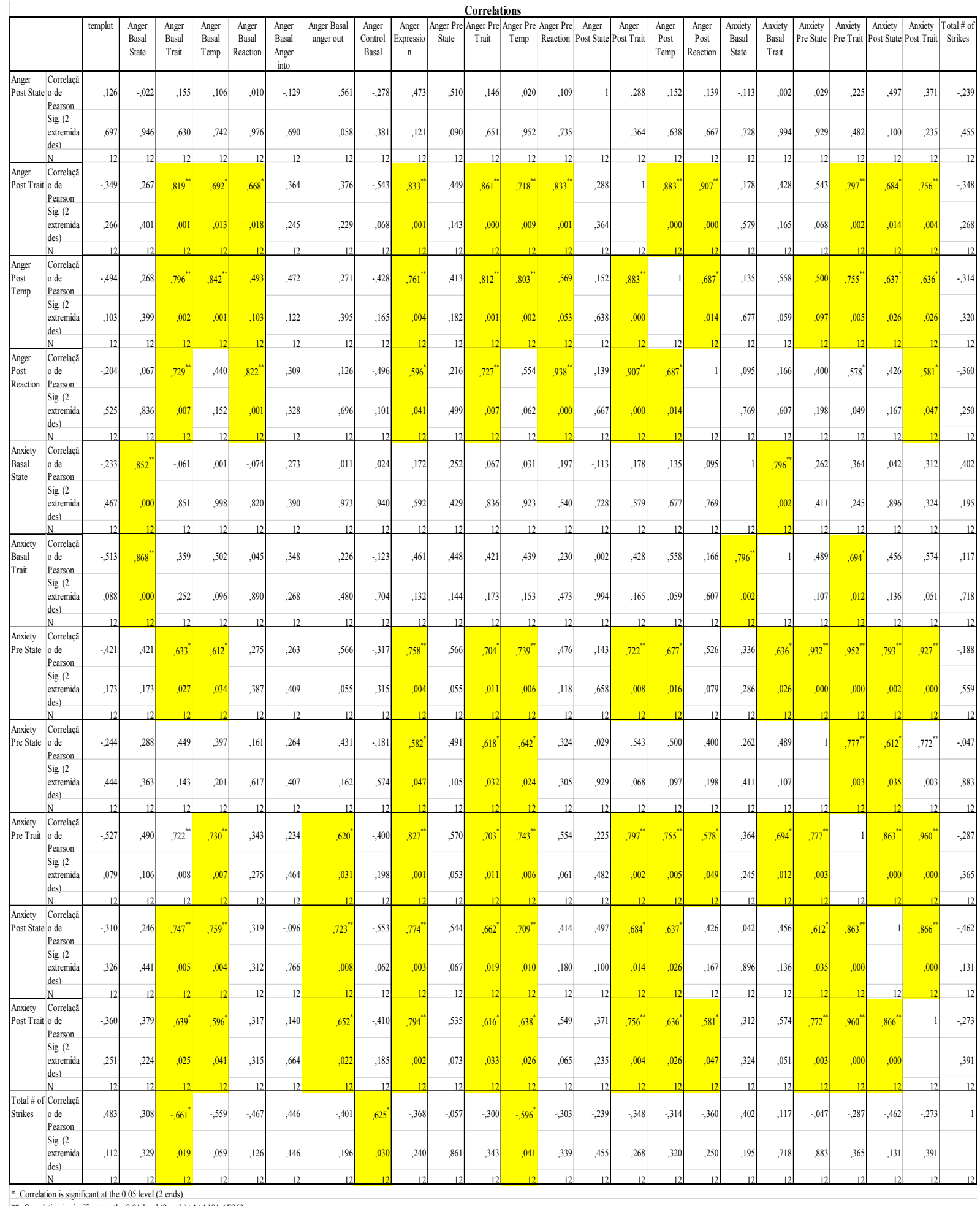

**. Correlation is significant at the 0.01 level (2 ends) +A+Al81:AF263

\section{Received: September 12th, 2018} Approved: April 21st, 2020 